Article

\title{
Thermal Contact Conductance-Based Thermal Behavior Analytical Model for a Hybrid Floor at Elevated Temperatures
}

\author{
Min Jae Park ${ }^{1}$, Jeong Ki Min ${ }^{2}$, Jaehoon Bae ${ }^{1}$ (I) and Young K. Ju ${ }^{1, *}$ \\ 1 School of Civil, Environmental, and Architectural Engineering, Korea University, Seoul 02481, Korea; \\ alswo8739@korea.ac.kr (M.J.P.); skycity-bjh@korea.ac.kr (J.B.) \\ 2 Fire Protection Evaluation Technology Center, Korea Conformity Laboratories, \\ Chungcheongbuk-do 28115, Korea; jkm927@kcl.re.kr \\ * Correspondence: tallsite@korea.ac.kr; Tel.: +82-2-3290-3327
}

Received: 27 August 2020; Accepted: 22 September 2020; Published: 24 September 2020

\begin{abstract}
Hybrid floors infilled with polymeric materials between two steel plates were developed as a prefabricated floor system in the construction industry. However, the floor's fire resistance performance has not been investigated. To evaluate this, fire tests suggested by the Korean Standards should be performed. As these tests are costly and time consuming, the number of variables were limited. However, many variables can be investigated in other ways such as furnace tests and finite element analysis (FEA) with less cost and time. In this study, furnace tests on heated surface areas smaller than $1 \mathrm{~m}^{2}$ were conducted to investigate the thermal behavior of the hybrid floor at elevated temperatures. To obtain the reliability of the proposed thermal behavior analytical (TBA) model, verifications were conducted by FEAs. Thermal contact conductance including interfacial thermal properties between two materials was adopted in the TBA model, and the values at elevated temperatures were suggested based on thermo-gravimetric analyses results and verified by FEA. Errors between the tests and TBA model indicated that the model was adequate in predicting the temperature distribution in small-scale hybrids. Furthermore, larger furnace tests and analysis results were compared to verify the TBA model's application to different sized hybrid floors.
\end{abstract}

Keywords: polymeric material; hybrid floor; thermal contact conductance; thermal behavior analytical model; fire resistance performance

\section{Introduction}

Prefabricated composite hybrid floors, which consist of polymeric materials between top and bottom steel plates, such as sandwich panels (Figure 1), were developed to apply to steel structures [1-9]. Because the polymeric materials in the floor have strong bond strengths with steel plates under large deformations, the hybrid floor exhibits fully composite and interaction behaviors under loading [1-3,10-12]. As bottom steel plates and bottom parts of polymeric materials lose their mechanical properties at elevated temperatures, wire meshes enhance the bending capacity of the floor. The structural performance of the floor at the ambient temperature was investigated, and the serviceability, including the floor vibration and damping ratio, was also studied [1-5]. The hybrid floor system with insulating materials for preventing fire were installed in two actual buildings, a church and a residential building. Floor vibration tests were conducted, and the dynamic characteristics of the buildings were investigated [5]. 


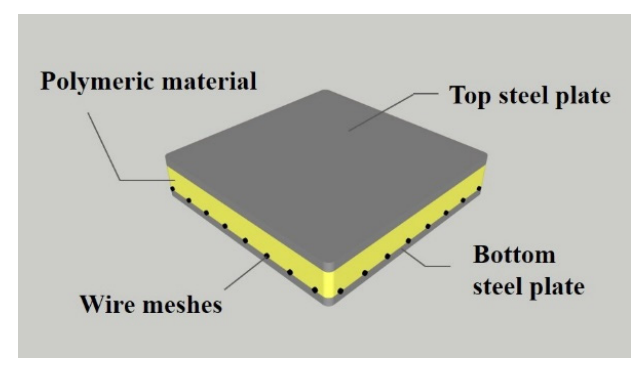

Figure 1. Components of the hybrid floor.

To be an absolute prefabricated floor system, this hybrid floor must exhibit the fire resistance performance required in the Republic of Korea. The fire resistance performances of horizontal members in buildings are evaluated by three criteria based on Korean Standards (KS) $[13,14]$. The stability-related deformation and rate of the deformation, insulation-related changes in temperatures, and integrity-related occurrences of flames at unheated surfaces during fire tests belong to the criteria. In the case of this floor system, fire tests were conducted on the horizontal equipment, and the lower parts of the specimen were heated by a standard-fire-heating-curve equal to the International Organization for Standardization (ISO) 834 curve $[15,16]$. When any criterion was unsatisfied, the time would be the fire resistance ratings of the specimen. Because there is no question of a flame appearing at the unheated surfaces of the hybrid floor, only the stability and insulation were used for evaluating the fire resistance performance of the floor. Preliminary fire tests were conducted to survey the behaviors at elevated temperatures caused by many factors such as the phase changes of polymeric materials, interfacial properties between the steel and polymeric material, and the possibility of flames in the polymeric materials [6-9]. These tests showed that many factors could predict the fire resistance performance of the hybrid floor.

The fire tests based on the KS and ISO are time intensive and costly to conduct. As the Republic of Korea has very few authorized furnaces, a long waiting time was required to conduct the tests, and few specimens could be investigated. Therefore, analytical studies or furnace tests with numerous variables were the most efficient ways to study the fire resistance performance of the hybrid floor $[17,18]$. The procedure for the analytical studies is shown in Figure 2. Thermal properties and the applied theories of heat transfer were quite important because the results of the heat transfer analysis determined the mechanical properties of the elements at elevated temperatures in the structural analysis. Thus, to improve the reliability of the analytical studies, accurate thermal properties including the interfacial properties of the composite members should be adopted.

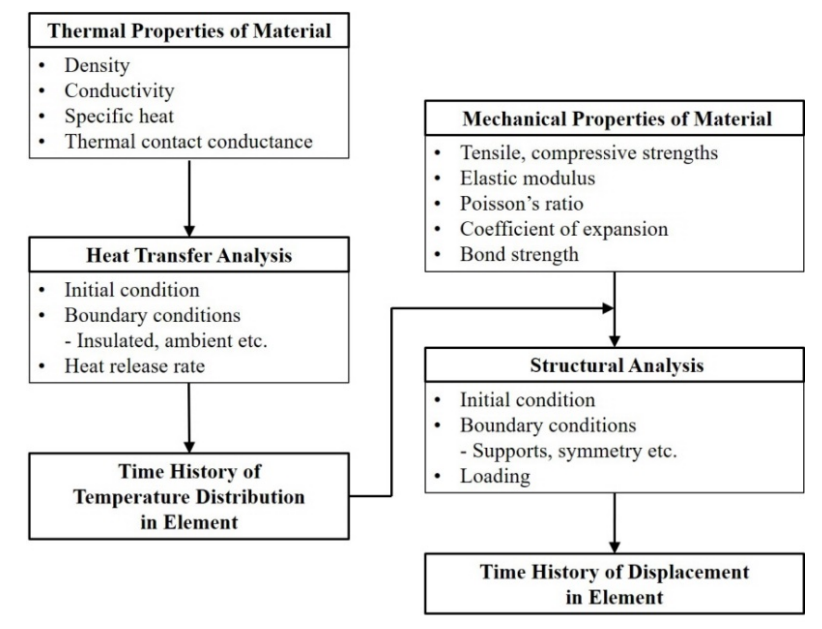

Figure 2. Procedure of the analytical studies for fire resistance. 
Studies on thermal contact conductance (TCC), an interfacial property, have been conducted since the 1950s [19]. TCC can be measured by the temperature drops $\left(\mathrm{T}_{2 \mathrm{~B}}-\mathrm{T}_{2 \mathrm{~A}}\right)$ between two materials owing to invisible interstitial gaps at the contact surfaces (A-B) as shown in Figure 3.

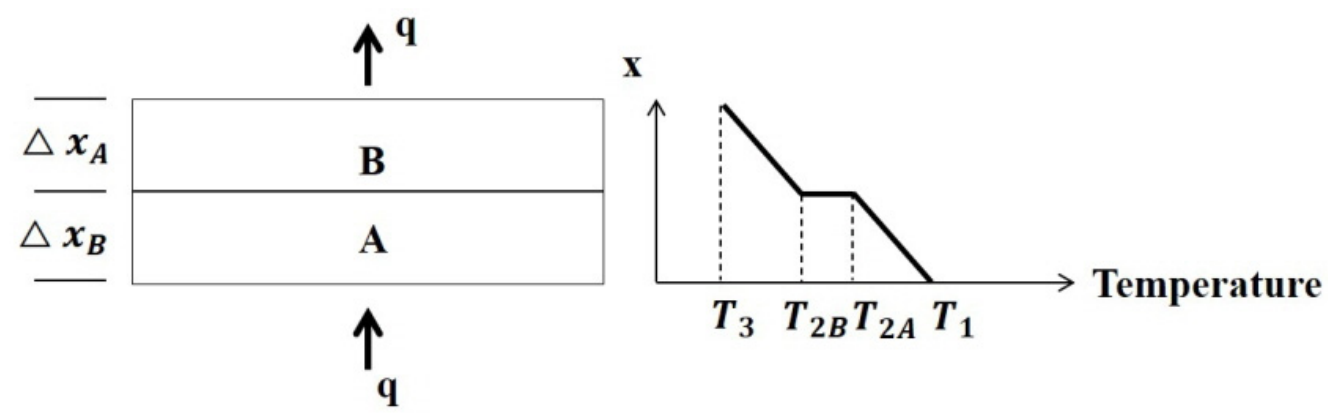

Figure 3. Diagram of thermal contact conductance.

For building structural members, studies on TCC have been conducted by researchers since the 2000s, and only the TCC between concrete and steel were investigated [20-26]. From the results of these studies, many researchers applied the TCC theory and the obtained values to the analytical modeling for estimating fire resistance performance. In addition, studies about TCC between metal and polymers were performed, and these results provided the values for the analytical modeling in this study [27-29]. The reason TCC should be considered in evaluating the fire resistance performance of hybrid floors is because the difference in temperature distribution (Figure 4) will determine inappropriate mechanical properties and predict invalid deformations at elevated temperatures.

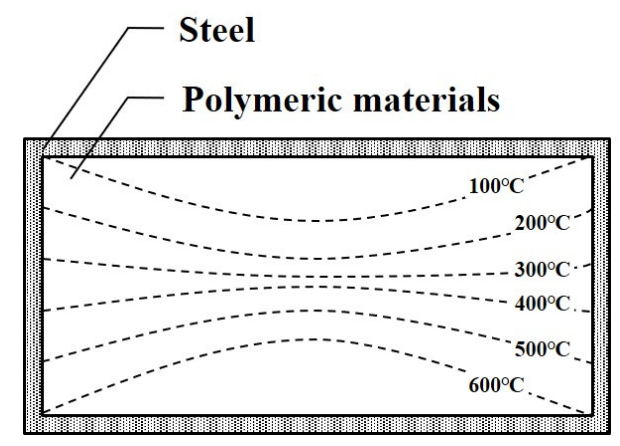

(a) without TCC

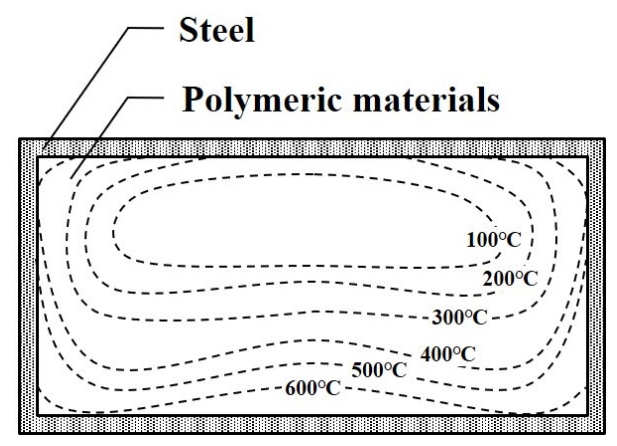

(b)with TCC

Figure 4. Examples of temperature distributions in hybrid floors: (a) without TCC (b) with TCC.

The aim of this study was to investigate the thermal behavior of a hybrid floor at elevated temperatures based on previous studies and propose an analytical model to predict the temperature distribution of elements that are the basis of estimations of fire resistance performance. In addition, the reliability of the proposed analytical model, a thermal contact conductance-based thermal behavior analytical (TBA) model, was enhanced by verifications using a finite element analysis (FEA) that simulated the furnace tests.

\section{State-of-the-Art Studies}

\subsection{Hybrid Floor}

The polymeric materials are a one of type of polyurethane formed by reacting a diisocyanate that contains phosphorous with a polyol mixture. The mechanical properties tests of polymeric materials were conducted based on the American Society for Testing and Materials (ASTM) and are listed in Table 1 [1-3]. Although the tensile, compressive strengths, and elasticity modulus of polymeric materials were much weaker than those of general steel plates, the ultimate strains of 
polymeric materials were much larger than those of general steel plates. Based on flexural tests of the hybrid floor, the experimental flexural strengths were $8 \%$ higher than theoretical plastic moment strengths [1-3]. For predicting the calibration of deformation, Kim [2] suggested that summation of theoretical bending and shear deformation should be divided by 0.85 . In addition, the FEA of the floor was performed to examine the state of stress generated between the steel plates and the polymeric materials [3]. Floor vibration of the floor that had both pined supports can be predicted by Steel Construction Institute (SCI) publication [4,30]. In addition, the floor vibration tests of actual buildings were performed, and the results exhibited that the floor showed equal performance of original steel structures slabs recommended by the American Institute of Steel Construction (AISC) [31].

Table 1. Mechanical properties of the polymeric materials [3].

\begin{tabular}{lc}
\hline \multicolumn{1}{c}{ Property } & Value \\
\hline$\rho:$ Density $\left(\mathrm{kg} / \mathrm{m}^{3}\right)$ & 1178 \\
$\sigma_{\mathrm{t}}$ : Tensile strength $(\mathrm{MPa})$ & 31.4 \\
$\mathrm{E}_{\mathrm{t}}$ : Modulus of elasticity in tension $(\mathrm{MPa})$ & 1277 \\
$\sigma_{\mathrm{c}}:$ Compressive strength $(\mathrm{MPa})$ & 23.1 \\
$\mathrm{E}_{\mathrm{c}}$ : Modulus of elasticity in compression $(\mathrm{MPa})$ & 461 \\
$\nu:$ Poisson's ratio & 0.39 \\
\hline
\end{tabular}

Preliminary fire tests in accordance with KS and ISO were conducted [5-7]. After $26 \mathrm{~min}$, the fire tests were stopped because of the spacers that were installed for improving the efficiency of the manufacturing process in the factory. From these tests results, $2 \sim 5 \mathrm{~mm}$ charred layer that behaved as an insulation material was revealed at the bottom part of the polymeric materials and heated through the exposed surfaces similar to the char of wood structures [32-35] and decomposition of sandwich systems [36] in fire conditions. In addition, a gap between the lower steel plates and charred layer occurred due to the air that inevitably appears in polymeric materials during the manufacturing process. These results indicate that the thermal performance of polymeric materials should be improved to be a fire-resistant structure. Finally, the fire-resistant polymeric material was developed and compared with the original materials through a thermal gravimetric analysis (TGA) as shown in Figure 5. TGA shows the residual mass for the test materials at elevated temperatures. In Figure 5, a differential thermal analysis (DTA) result that provides data on the transformations that have occurred such as phase change for fire-resistant polymeric materials were neglected because the DTA result showed that those values were very small. This meant that the latent heat of polymeric materials due to phase change can be ignored because DTA shows the latent heat of materials at elevated temperatures. The differences between the original polymeric materials and fire-resistant polymeric materials were combustibility and the sustainability of the charred state that would explain the results of the tests.

\subsection{Thermal Contact Conductance Studies for Structural Elements}

Although fire studies were conducted on various structural members, the heat transfer analysis containing basic heat transfer theory - conduction, convection, and radiation-and moisture changes did not include the interface between two materials. For this reason, the numerical studies usually exhibit more conservative results than the experimental studies [37,38]. Therefore, some researchers suggested that the TCC between two materials should be considered and that it would make the results more significant compared with those that ignore the TCC $[20,21,26]$. Many researchers conducted tests to determine the TCC between concrete and steel in structural members. Based on these studies, the values of the TCC range from 38.1 to $200 \mathrm{~W} / \mathrm{m}^{2} \cdot \mathrm{K}$ [20-26]. However, there is no study on the TCC between polymers and steel that can be applied to a floor under fire. 


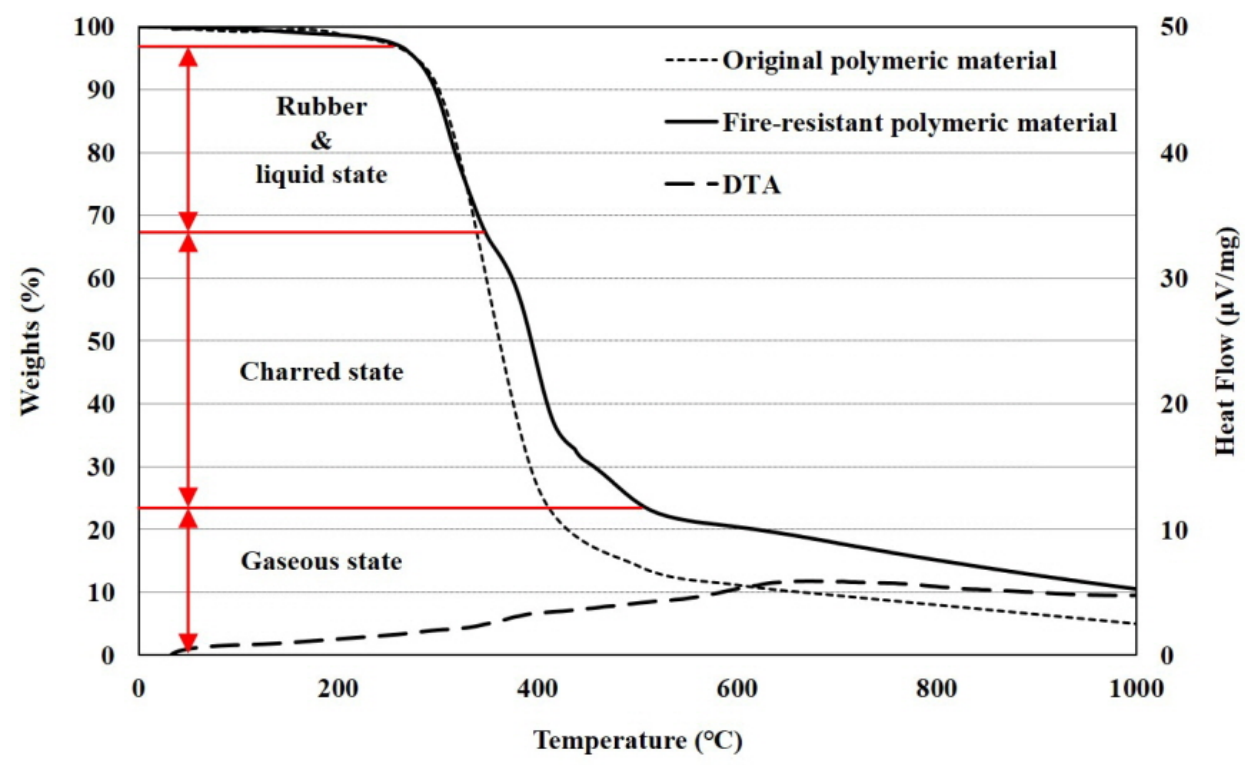

Figure 5. Thermal gravimetric analysis (TGA) and differential thermal analysis (DTA) results of original and fire-resistant polymeric materials.

\subsection{Thermal Contact Conductance between Polymer and Metal}

Because there is no study for the TCC between polymers and steel, the values of the TCC between the polymer and metal were used. Fuller and Marotta [27] proposed a TCC model of polymer/metal and verified it with experimental data. The values of the TCC obtained by the model and data were between 40 and $270 \mathrm{~W} / \mathrm{m}^{2} \cdot \mathrm{K}$ at various contact pressures. Bahrami et al. [28] proposed the compact analytical thermal contact resistance (TCR) model that was the inverse of the TCC and verified it with 13 polymer-metal data sets containing 127 experimental data points. The values of the TCC by the compact analytical model had a range of $22-250 \mathrm{~W} / \mathrm{m}^{2} \cdot \mathrm{K}$ at various contact pressures. Gibbins [29] suggested a TCR value of approximately $8 \mathrm{~K} / \mathrm{W}$ at atmospheric pressure for a specimen with a $25.4 \mathrm{~mm}$ diameter. Based on that result, the TCC can be obtained as $246.7 \mathrm{~W} / \mathrm{m}^{2} \cdot \mathrm{K}$. In reference to the studies, the TCC values between polymer and metal with various air pressures were between 40 and $270 \mathrm{~W} / \mathrm{m}^{2} \cdot \mathrm{K}$.

\section{Thermal Behavior at Elevated Temperatures}

\subsection{Furnace Tests}

Furnace tests with a $0.01 \mathrm{~m}^{2}$ heated surface were conducted to investigate the fire resistance performance of the hybrid floor. The specimen size and setup of the furnace test known as a cone calorimeter [39-46] are shown in Figure 6. The aim of the tests was to effectively investigate the thermal behavior of the hybrid floor at elevated temperatures. The heated surface was uniformly heated at a rate of $30 \mathrm{~kW}$ for $24 \mathrm{~min}$. The k-type thermo-couples that have $0.75 \%$ errors were installed at heated and unheated surfaces. The test was stopped when an unexpected excessive deformation occurred that was considered in the other tests. The temperature results of the heated, unheated, and side surface are shown in Figure 7. 


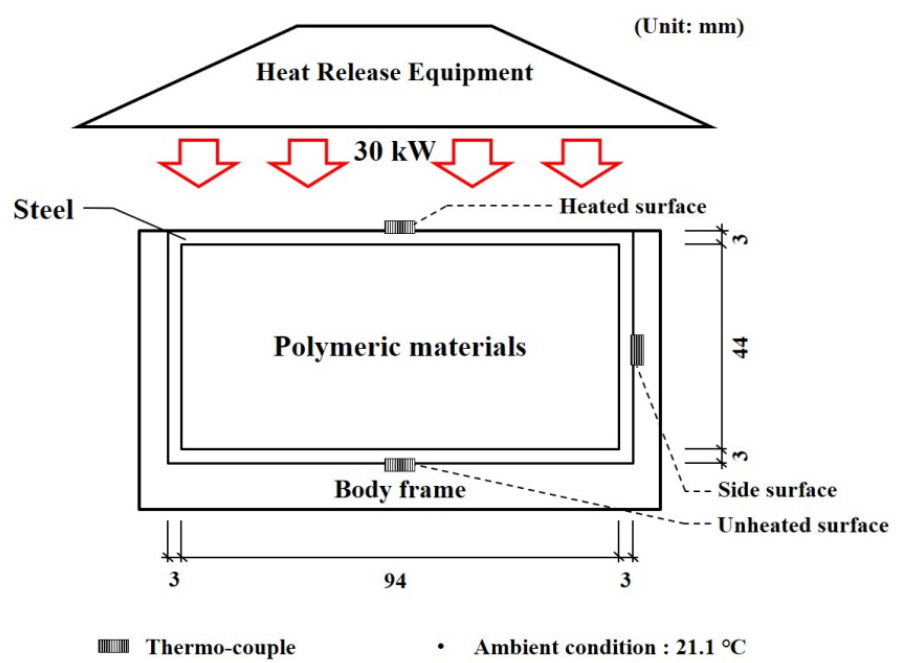

(a) Section elevation

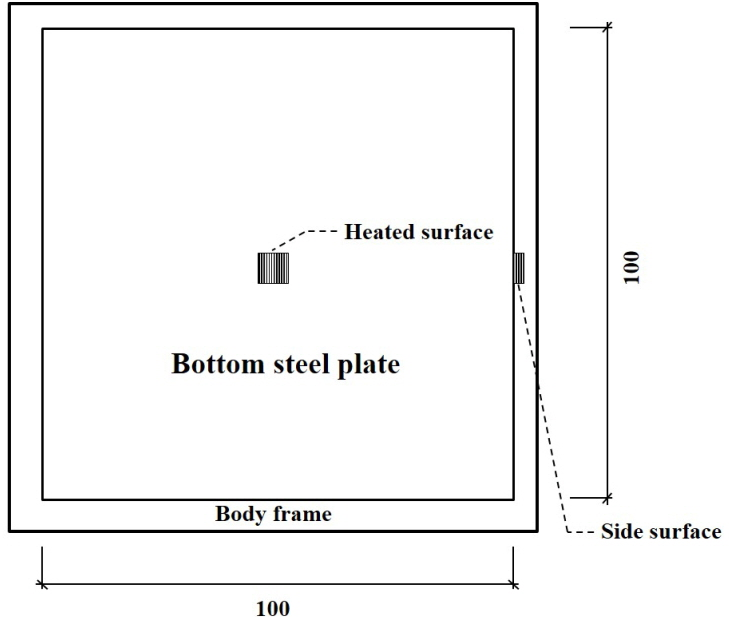

(b) Plan

Figure 6. Set-up of furnace tests: (a) Section elevation (b) Plan.

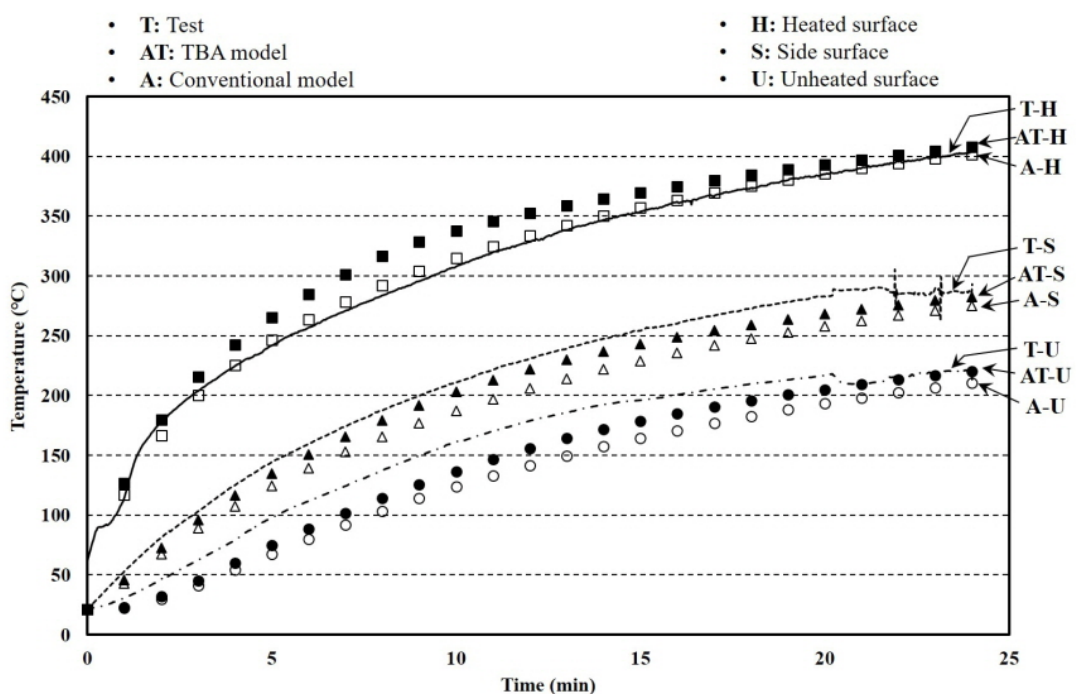

Figure 7. Temperature results of furnace tests and finite element analysis (FEA). 


\subsection{Insulated Furnace Test}

The difference from the previous furnace tests was the boundary conditions of the unheated and side surfaces. The unheated surfaces of this test were perfectly insulated, and this led to the specimen's elevated temperature. The size of the specimen and the setup of the insulated furnace test are shown in Figure 8. The aim of the tests was to investigate the thermal behavior of the hybrid floor at a more extreme condition than that of the cone calorimeter tests because there was little significant temperature and phase change during the previous tests. The k-type thermo-couples that have $0.75 \%$ errors were installed at the unheated surface. The surface was heated for $54 \mathrm{~min}$ by the heating curve that targeted the standard curve, and the unheated and side surfaces were insulated as shown in Figure 9. Therefore, the temperature changes in the specimen showed large differences.

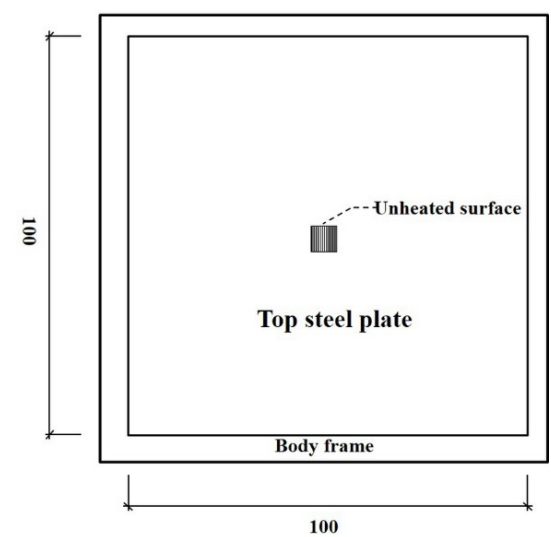

(a) Left elevation

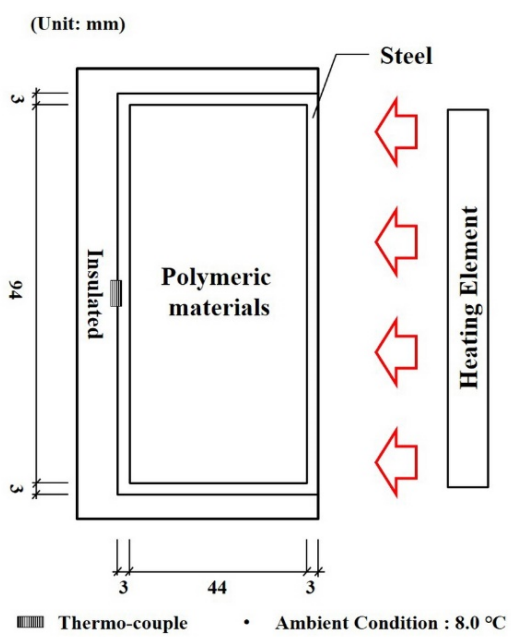

(b) Section elevation

Figure 8. Setup of insulated furnace tests: (a) Left elevation (b) Section elevation.

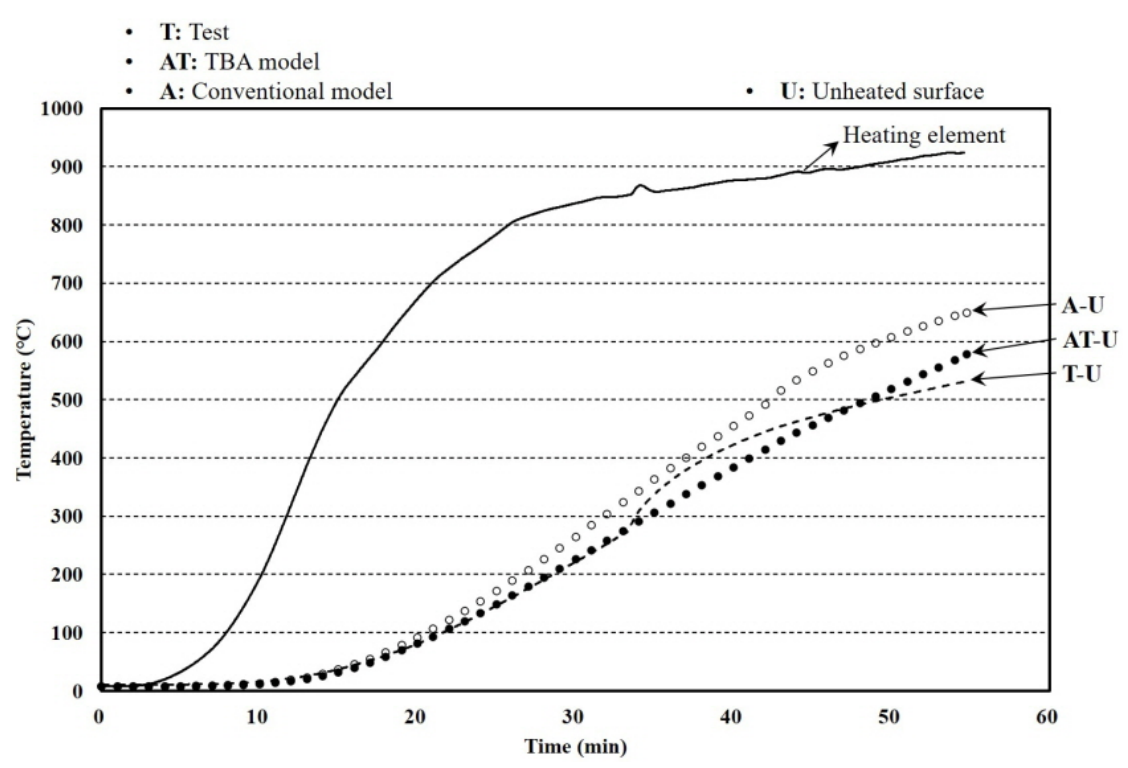

Figure 9. Temperature results of insulated furnace tests and FEA.

\subsection{Thermal Behavior Based on the Furnace Tests}

The phase changes of the hybrid floor at elevated temperature were divided into three stages as shown in Figure 10. First, the polymeric materials in the floor were in the solid state. The first stage was called the solid state. In the solid state, the properties of the polymeric materials were controlled only by the temperatures. Second, the polymeric materials in the floor displayed rubber and liquid state, 
and the rubber state and liquefied polymeric materials turned into charred polymeric materials or air. The second stage was called the partially charred state. In the partially charred state, air created a large gap between the polymeric materials and heated surface. Finally, the charred polymeric materials created a layer between the solid-state polymeric materials and lower steel plates that were the heated surface in the tests. The third stage was called the fully charred state, and the thickness of the charred layer remained at 2-5 $\mathrm{mm}$ that was disclosed in the preliminary fire furnace tests. As this layer behaved as an insulation layer in fully charred state, the heat transfer from the heated surface to polymeric materials was weak, and the heat flow detoured to the sides or the weak spots in the charred layer. Based on the TGA results, the range of temperatures for charred were $370-500{ }^{\circ} \mathrm{C}$, and the polymeric materials remained perfectly charred and in a gaseous state over $500{ }^{\circ} \mathrm{C}$.

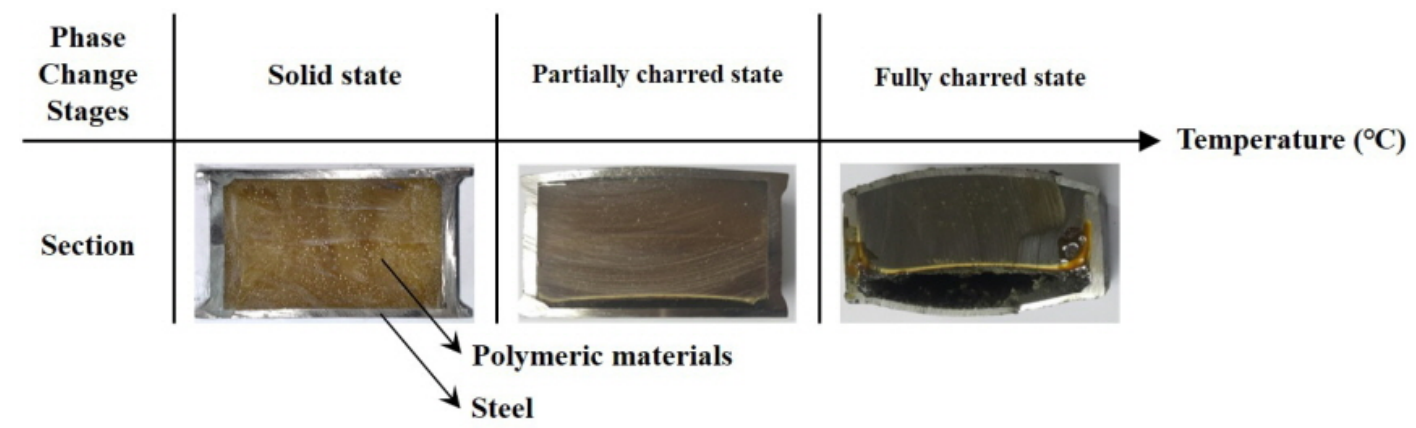

Figure 10. Three phase change stages at elevated temperatures.

\section{Verifications with Finite Element Analysis}

To apply the thermal behavior to predict the temperature distribution of the floor, the reliability of the TBA model should be obtained. In this study, the reliability of the TBA model was obtained by an FEA that simulates furnace tests. The FEA program ABAQUS 2017 was used. The DC3D8, which is an 8-node linear heat transfer brick, was used to generate the meshes. The material properties including density, thermal conductivity, and specific heat at elevated temperatures of steel were obtained from Eurocode 3 [47]. Other material properties including density, thermal conductivity, and specific heat of polymeric materials below $300{ }^{\circ} \mathrm{C}$ were obtained from material tests and linear proportional assumptions based on the standards [48]. The tests, known as the flash method used to measure values of thermal diffusivity of a wide range of solid materials, based on the standards measure the thermal diffusivity that consists of specific heat, density, and thermal conductivity. The material properties of polymeric materials over $500{ }^{\circ} \mathrm{C}$ were assumed as air and obtained from a study [49]. The TCC between steel and polymer at ambient temperature was determined by previous studies [27-29] as $250 \mathrm{~W} / \mathrm{m}^{2} \cdot \mathrm{K}$. The reduction ratio of TCCs at elevated temperatures followed the results of the TGA with insignificant modification based on FEA results and previous TCC studies between polymers and metal. The boundary conditions, including the heat transfer, convection, and radiation, at heated and unheated surfaces, were determined by several studies [47,50-68]. A summary of the material and interfacial properties is shown in Figures 11-13. The proposed TCC at elevated temperatures in this study can be written as

$$
\operatorname{TCC}\left(W / m^{2} \cdot K\right)=\left\{\begin{array}{cc}
250 & \left(T \leq 260{ }^{\circ} \mathrm{C}\right) \\
250-0.6932(T-260) & \left(260{ }^{\circ} \mathrm{C}<T \leq 370{ }^{\circ} \mathrm{C}\right) \\
173.75-1.3875(T-370) & \left(370{ }^{\circ} \mathrm{C}<T \leq 420^{\circ} \mathrm{C}\right) \\
104.38-0.2734(T-420) & \left(420{ }^{\circ} \mathrm{C}<T \leq 500^{\circ} \mathrm{C}\right) \\
82.5-0.05438(T-500) & \left(50{ }^{\circ} \mathrm{C}<\mathrm{T} \leq 1000^{\circ} \mathrm{C}\right) \\
55.31 & \left(1000{ }^{\circ} \mathrm{C}<\mathrm{T}\right)
\end{array}\right.
$$


where $T$ is the temperature. The furnace tests were selected to verify the TBA model based on the FEA. In addition, other furnace tests had a 6.25 times larger heated surface and were used to obtain the reliability of the TBA model for larger-scale tests. The results of the conventional model that simulates the furnace tests without the TCC were also compared to determine the importance of the TCC in this study.

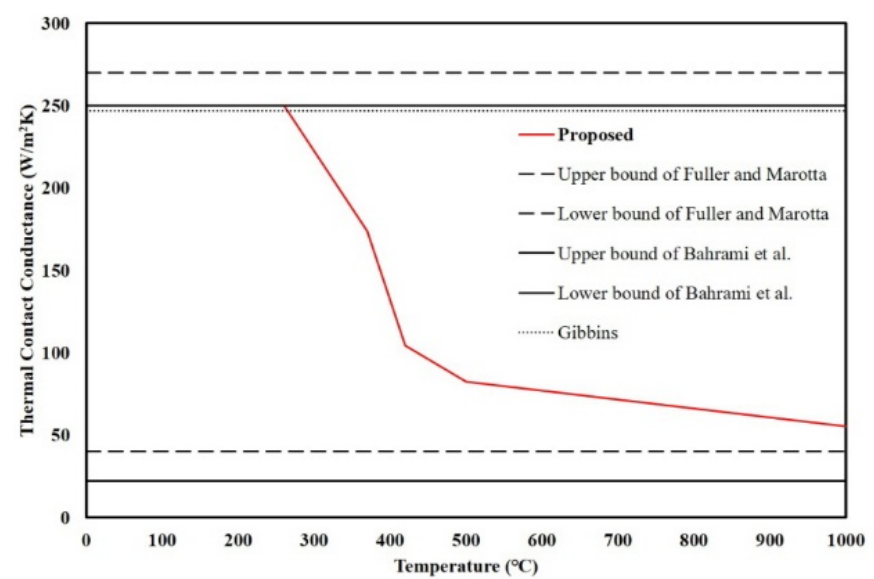

Figure 11. Thermal contact conductance between the steel and polymer at elevated temperatures.

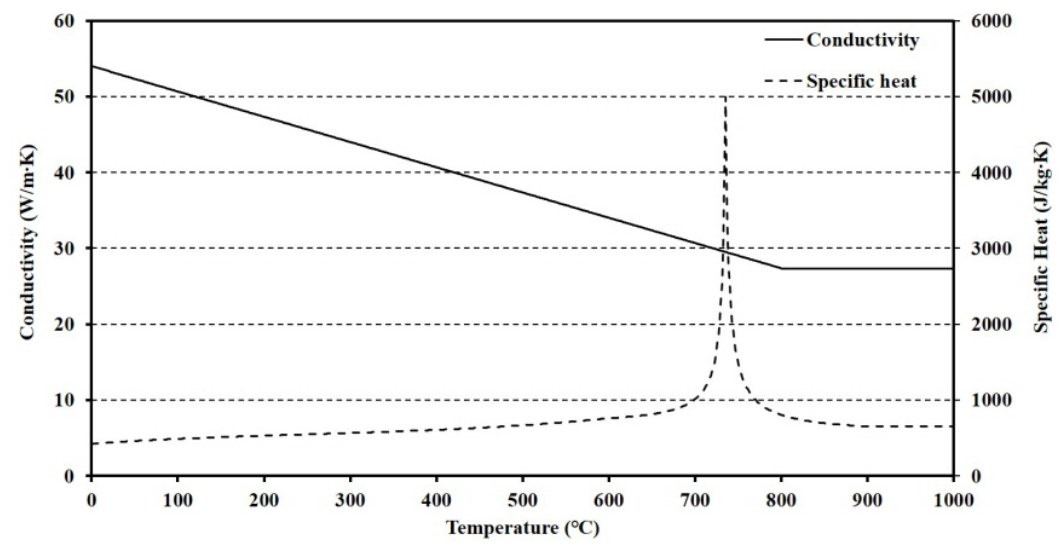

Figure 12. Conductivity and specific heat of steel at elevated temperatures.

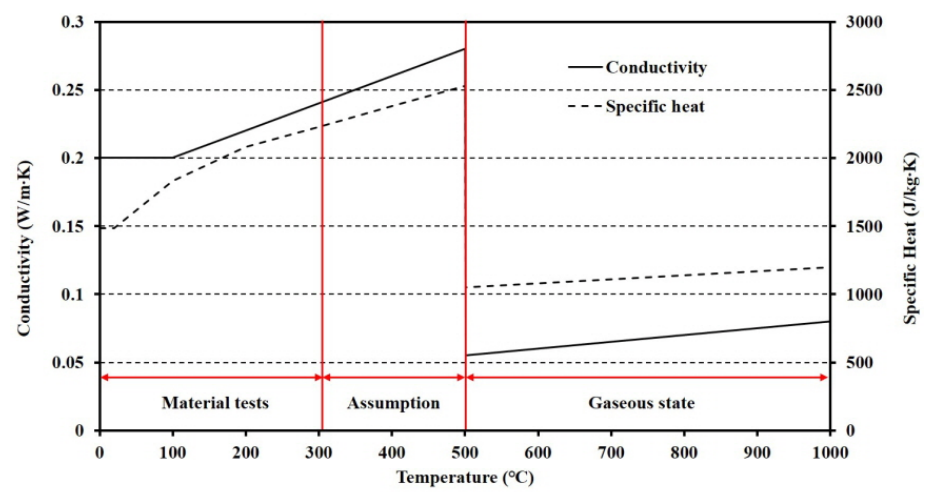

Figure 13. Conductivity and specific heat of polymeric materials at elevated temperatures.

\subsection{Furnace Tests}

The boundary conditions showing the emissivity and convection coefficients in the FEA for the heated and unheated surfaces are listed in Table 2. The reason the convection at the unheated surfaces was not considered was because of the body frame that fixed the specimen surrounding the unheated surfaces as shown in Figure 6. The average errors of the analysis results from the TBA and conventional 
models compared with the test results were $9.60 \%$ and $15.90 \%$, respectively, while the corresponding standard deviations of the errors were $14.09 \%$ and $13.44 \%$, as shown in Table 3 . The error reduction of the TBA model compared with the conventional model was $60.38 \%$. The reason the errors showed these larger results was because the thermal lag time was ignored in the interstitial properties and this caused a significant difference at the early time [69]. The errors at a specific time can be written as

$$
\varepsilon_{\text {time }}(\%)=\left|\frac{\Delta T_{\text {analysis }}-\Delta T_{\text {test }}}{\Delta T_{\text {test }}}\right|=\left|\frac{\left(T_{\text {analysis,time }}-T_{\text {initial }}\right)-\left(T_{\text {test }, \text { time }}-T_{\text {initial }}\right)}{\left(T_{\text {test }, \text { time }}-T_{\text {initial }}\right)}\right|
$$

where $T$ is the temperature. In calculating the errors' average and standard deviation, the unheated surfaces that significantly influenced the TBA model in this study were considered. The small temperature differences at the heated surfaces were generated by the initial temperature of the specimen because of the error in the thermocouples.

Table 2. Boundary conditions of furnace tests in FEA.

\begin{tabular}{|c|c|c|c|c|c|c|}
\hline \multirow[b]{2}{*}{ Tests } & \multicolumn{3}{|c|}{ Heated Surface } & \multicolumn{3}{|c|}{ Unheated Surface } \\
\hline & $\begin{array}{l}\text { Convective } \\
\text { Coefficient } \\
\left(\mathrm{W} / \mathrm{m}^{2} \cdot \mathrm{K}\right)\end{array}$ & $\begin{array}{l}\text { Emissivity } \\
\text { of Fire }\end{array}$ & $\begin{array}{l}\text { Surface Emissivity } \\
\text { of Member }\end{array}$ & $\begin{array}{l}\text { Convective } \\
\text { Coefficient } \\
\left(\mathrm{W} / \mathrm{m}^{2} \cdot \mathrm{K}\right)\end{array}$ & $\begin{array}{l}\text { Emissivity } \\
\text { of Fire }\end{array}$ & $\begin{array}{l}\text { Surface Emissivity } \\
\text { of Member }\end{array}$ \\
\hline Furnace tests & 10 & 1 & 0.7 & - & 1 & 0.7 \\
\hline $\begin{array}{l}\text { Insulated furnace tests } \\
\text { Larger }\end{array}$ & 25 & 0.8 & 0.7 & & Insulated & \\
\hline $\begin{array}{l}\text { furnace tests (Thickness: } \\
\qquad 50 \mathrm{~mm})\end{array}$ & 25 & 1 & 0.7 & 4 & 1 & 0.7 \\
\hline $\begin{array}{c}\text { Larger } \\
\text { furnace tests } \\
\text { (Thickness: } 60 \mathrm{~mm} \text { ) }\end{array}$ & 120 & 1 & 0.9 & 4 & 1 & 0.7 \\
\hline
\end{tabular}

Table 3. Errors average and deviation of analysis results compared with the test results.

\begin{tabular}{|c|c|c|c|c|c|}
\hline \multirow[b]{2}{*}{ Tests } & \multicolumn{2}{|c|}{ TBA Model } & \multicolumn{2}{|c|}{ Conventional Model } & \multirow{2}{*}{$\begin{array}{c}\text { Error Reduction } \\
\left(\mathrm{m}_{\mathrm{wT}}\right) \\
/\left(\mathrm{m}_{\mathrm{woT}}\right)\end{array}$} \\
\hline & $\begin{array}{c}\text { Average } \\
\left(\mathrm{m}_{\mathrm{wT}}\right)\end{array}$ & $\begin{array}{l}\text { Standard } \\
\text { Deviation }\end{array}$ & $\begin{array}{c}\text { Average } \\
\left(\mathrm{m}_{\text {wot }}\right)\end{array}$ & $\begin{array}{l}\text { Standard } \\
\text { Deviation }\end{array}$ & \\
\hline Furnace tests & $9.60 \%$ & $14.09 \%$ & $15.90 \%$ & $13.44 \%$ & $60.38 \%$ \\
\hline Insulated furnace tests & $14.74 \%$ & $24.30 \%$ & $20.61 \%$ & $23.26 \%$ & $71.52 \%$ \\
\hline $\begin{array}{l}\text { Larger } \\
\text { furnace tests (Thickness: } 50 \mathrm{~mm} \text { ) }\end{array}$ & $20.99 \%$ & $23.49 \%$ & $23.77 \%$ & $24.63 \%$ & $88.30 \%$ \\
\hline $\begin{array}{c}\text { Larger } \\
\text { furnace tests } \\
\text { (Thickness: } 60 \mathrm{~mm} \text { ) }\end{array}$ & 26.03 & $33.31 \%$ & $35.86 \%$ & $32.58 \%$ & $72.59 \%$ \\
\hline
\end{tabular}

\subsection{Insulated Furnace Tests}

The boundary conditions showing the emissivity and convection coefficients in the FEA at the heated surfaces are listed in Table 2; moreover, the unheated surfaces were perfectly insulated. In the insulated furnace tests, only the temperatures of the furnace and unheated surface were measured due to a limitation of the furnace shown in Figure 8. The average error of the analysis results with the TBA and conventional models were $14.74 \%$ and $20.61 \%$, respectively, while the error deviations were $24.30 \%$ and $23.26 \%$, as listed in Table 3. The error reduction of the TBA model compared with the conventional model was $71.52 \%$. The average error reduction was $65.95 \%$. Based on the verification results of the two furnace tests, the TBA model proved to be a valid thermal model to predict the temperatures of the hybrid floor at elevated temperatures.

\subsection{Larger Furnace Tests}

The aim for verifying the larger furnace test results was to obtain the reliability of predicting the temperature distribution of a larger-sized floor with the FEA results. The specimen size and the test setup are shown in Figure 14. The k-type thermo-couples that have $0.75 \%$ errors were installed at heated, unheated, and side surfaces. The boundary conditions showing the emissivity and convection 
coefficients in the FEA at the heated and unheated surfaces are listed in Table 2. As the heating capacity of the larger furnace was irregular, two tests results were used. The test with a 60-mm specimen thickness showed the largest heat capacity, and the other test that had a 50-mm specimen thickness took the longest time to complete. The test results and analysis are shown in Figures 15 and 16. The average errors for the $50-\mathrm{mm}$ analysis results with the TBA and conventional models were $20.99 \%$ and $23.77 \%$, respectively, while the corresponding error deviations were $23.49 \%$ and $24.63 \%$. The average errors for the $60-\mathrm{mm}$ analysis results with the TBA and conventional models were $26.03 \%$ and $35.86 \%$, respectively, while the corresponding error deviations were $33.31 \%$ and $32.58 \%$. The error reductions for the 50 - and 60-mm TBA models compared with the conventional model were $88.30 \%$ and $72.59 \%$, respectively. The entire average error reduction including the smaller furnace tests was $73.20 \%$. The reliability of the TBA model applied to larger furnaces that was proposed for smaller furnace tests was obtained by the above results.

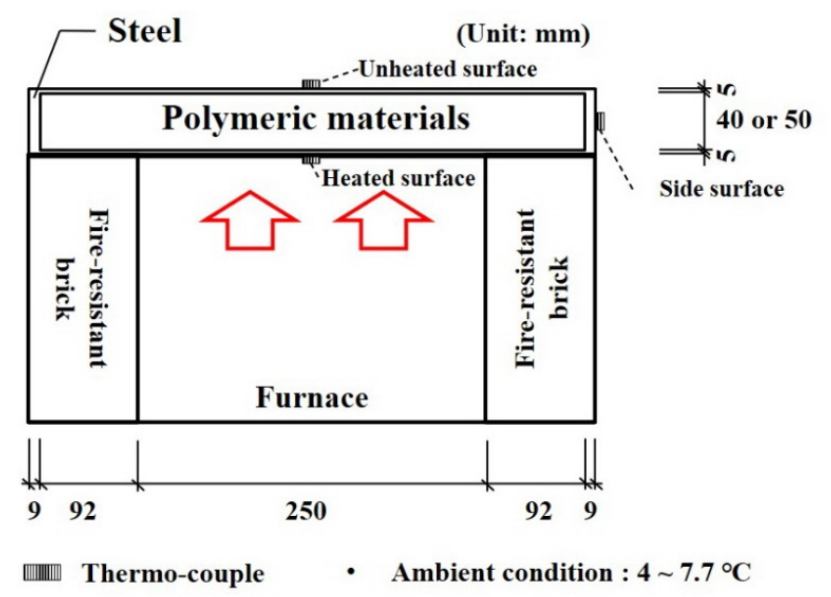

(a) Section elevation

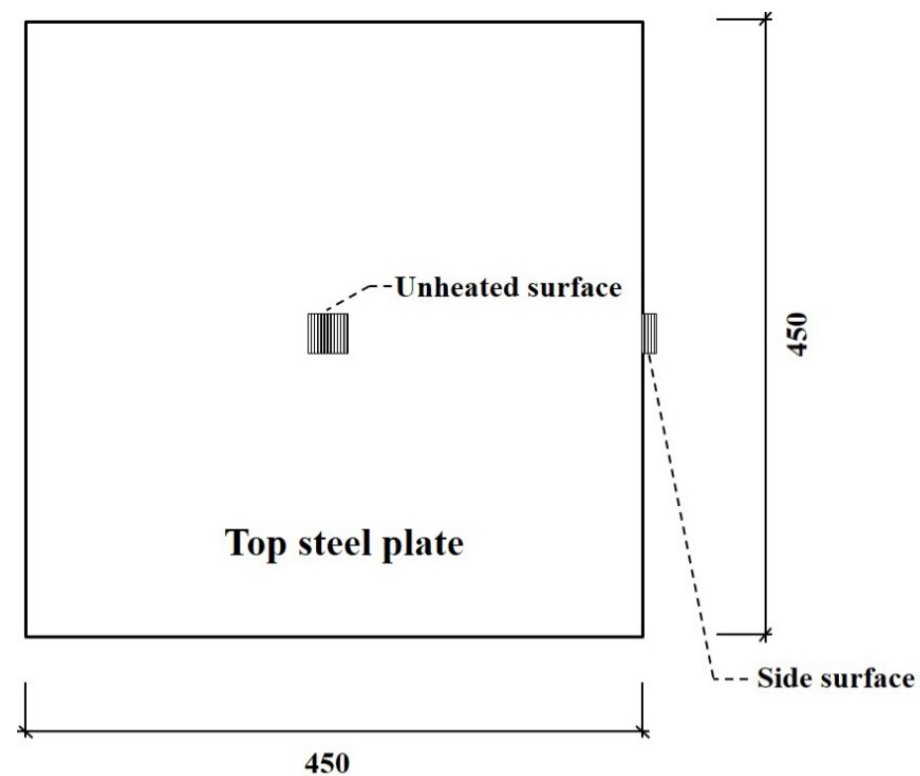

(b) Plan

Figure 14. Setup of larger furnace tests: (a) Section elevation (b) Plan. 


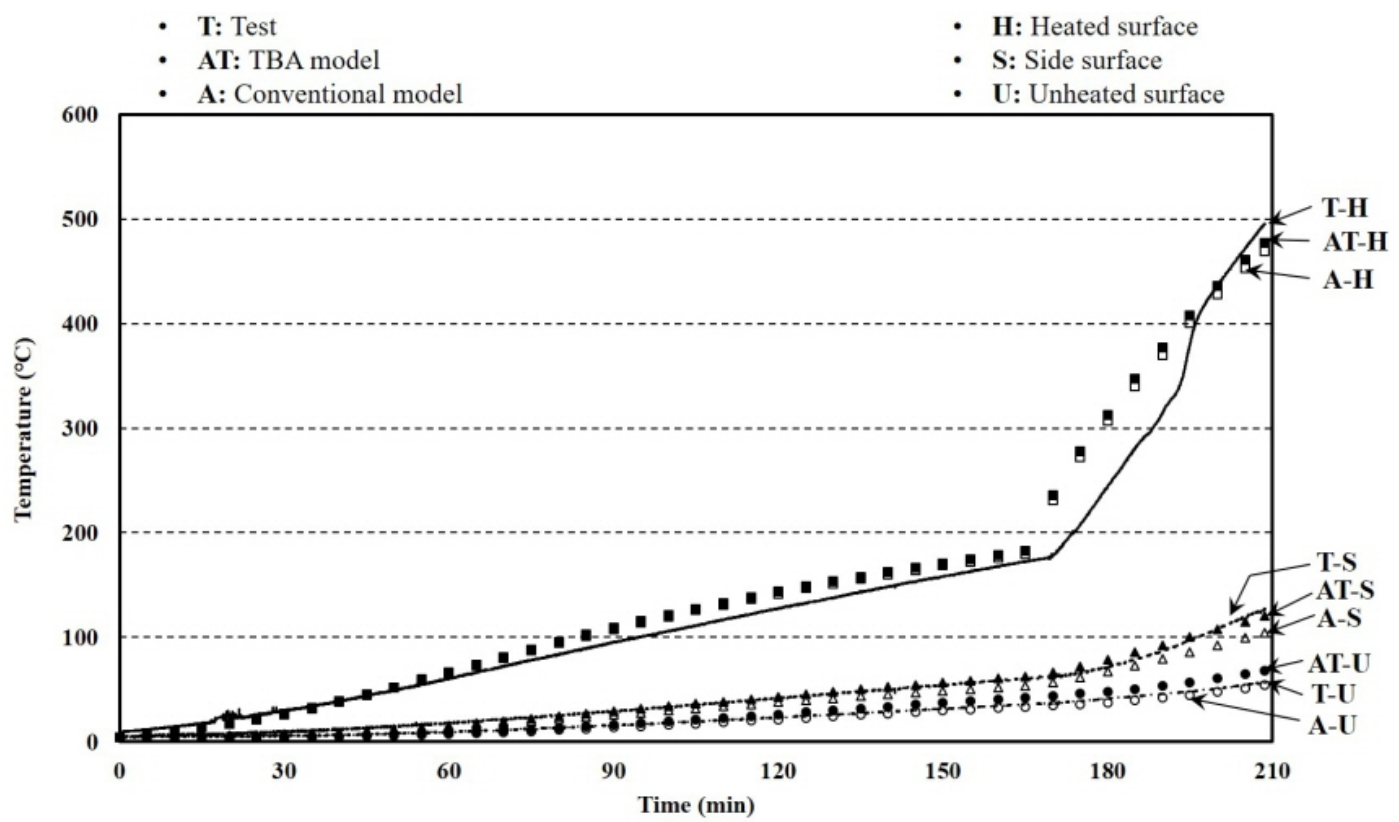

Figure 15. Temperature results of larger furnace tests and FEA with a 50-mm thickness.

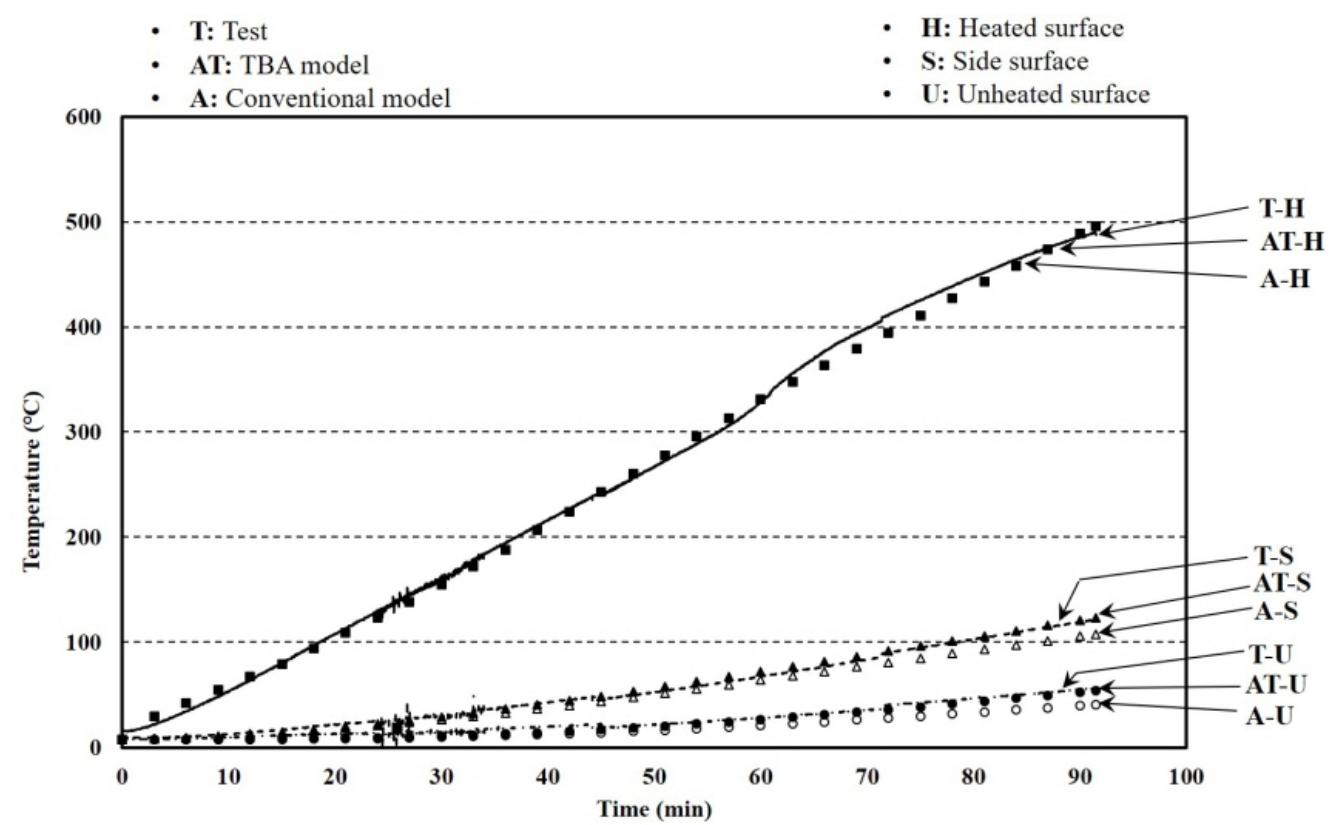

Figure 16. Temperature results of larger furnace tests and FEA with a 60-mm thickness.

\section{Conclusions}

A hybrid floor was developed as a prefabricated floor system for steel structures. Based on previous studies, the floor has a good structural performance and serviceability. To be a more effective floor that can be applied to actual buildings without insulating materials for fire prevention, the floor should show an acceptable fire resistance performance as evaluated through tests conducted in Korea based on the KS. As the fire tests demand enormous costs and time to conduct, the number of specimen variables was limited. Therefore, more efficient methods such as the FEA and furnace tests that allowed for numerous variables were performed in this study to investigate the thermal behavior of the hybrid floor at elevated temperatures. In addition, FEAs with ABAQUS 2017 were performed to verify the TBA model, and larger furnace test results were used to verify the effect on larger-sized floors. In accordance with the furnace tests and FEA, the following points summarizes the results presented herein. 
(1) The application of TCC related to the contact issues between two materials for predicting the time history of temperature distributions obtained more reliable analysis results compared with the results without considering TCC. The analysis results with TCC showed errors reduced by $73.20 \%$ compared with the results without TCC.

(2) When the TCC between polymeric materials and steel at elevated temperatures could not be measured, it can be determined by the results of the TGA that was reliable deduction based on previous studies and the analysis results.

(3) The proposed TBA model showed average errors of $17.84 \%$ in the analysis results compared with the time history of tests results. This means the proposed analytical modelling was a reliable way to predict the temperature distribution of the hybrid floor at elevated temperatures.

(4) When the polymeric materials exhibited thermal properties and TGA results analogous with the ones in this study, the TCC at elevated temperatures with steel in Equation (1) could be used to calculate the temperature distribution in the elements that contained contact problems between polymeric materials and steel.

Author Contributions: Conceptualization, M.J.P., J.K.M. and Y.K.J.; methodology, Y.K.J.; software, M.J.P.; validation, M.J.P., Y.K.J.; investigation, M.J.P., J.B., Y.K.J.; data curation, M.J.P., J.K.M.; writing-original draft preparation, M.J.P., Y.K.J.; writing—review and editing, M.J.P., Y.K.J.; visualization, M.J.P., J.B.; supervision, Y.K.J.; project administration, Y.K.J.; funding acquisition, Y.K.J. All authors have read and agreed to the published version of the manuscript.

Funding: This work was supported by the National Research Foundation of Korea (NRF) funded by the Korean government (MSIT) [grant numbers NRF-2020R1A2C3005687, NRF-2018R1A4A1026027]; and the Korea Agency for Infrastructure Technology Advancement (KAIA) [grant number 20AUDP-B100343-06].

Conflicts of Interest: The authors declare no conflict of interest.

\section{References}

1. Kim, Y.Y.; Ryu, J.; Yoon, S.W.; Ju, Y.K. Flexural behavior of iFLASH system with no blast metal cleaned steel plates. J. Korean Soc. Adv. Comp. Struct. 2015, 6, 30-37. [CrossRef]

2. Kim, Y.Y. Flexural Capacity of Nano-Composite Infilled iFLASH System. Master's Thesis, Korea University, Seoul, Korea, 2016.

3. Ryu, J.; Kim, Y.Y.; Park, M.W.; Yoon, S.-W.; Lee, C.-H.; Ju, Y.K. Experimental and numerical investigations of steel-polymer hybrid floor panels subjected to three-point bending. Eng. Struct. 2018, 175, 467-482. [CrossRef]

4. Ryu, J.H.; Ju, Y.K.; Yoon, S.W. Dynamic characteristic of composite beam using the sandwich plate system. J. Korean Assoc. Spat. Struct. 2014, 14, 65-72. [CrossRef]

5. Lee, J.H.; Lim, D.S.; Ju, Y.K.; Yoon, S.-W. Vibration characteristics of iFLASH system. J. Korean Assoc. Spat. Struct. 2016, 16, 89-97. [CrossRef]

6. Park, M.J.; Ryu, J.; Min, J.K.; Ju, Y.K. Thermal insulation performance of PCM infilled floor system using heat transfer analysis. J. Korean Soc. Adv. Comp. Struct. 2017, 8, 1-8. [CrossRef]

7. Park, M.J.; Min, J.K.; Yoon, S.W.; Ju, Y.K. Behavior characteristics of PCM infilled floor system at elevated temperature. J. Korean Assoc. Spat. Struct. 2017, 17, 33-41. [CrossRef]

8. Park, M.J.; Ju, Y.K.; MIn, J.K.; Yoon, S.W. Fire resistance performance of prefabricated composite floor system infilled with phase change material. In Proceedings of the 39th IABSE Symposium-Engineering the Future, Vancouver, BC, Canada, 21-23 September 2017.

9. Tian, Y.Q. Thermal Characteristics of PCM Infilled Hollow Hybrid Floor. Master's Thesis, Korea University, Seoul, Korea, 2019.

10. Nethercot, D.A. Composite Construction; Spon Press: London, UK, 2003.

11. Oehlers, D.J.; Bradford, M.A. Composite Steel and Concrete Structural Members; Pergamon Press: Oxford, UK, 1995.

12. Oehlers, D.J.; Bradford, M.A. Elementary Behaviour of Composite Steel \& Concrete Structural Members; Butterworth Heinemann: Oxford, UK, 1999. 
13. Korean Agency for Technology and Standards. Methods of Fire Resistance Test for Elements of Building Construction-General Requirements; KS F 2257-1; Korean Agency for Technology and Standards: Seoul, Korea, 2014.

14. Korean Agency for Technology and Standards. Methods of Fire Resistance Test for Elements of Building Construction-Specific Requirements for Loadbearing Horizontal Separating Elements; KS F 2257-5; Korean Agency for Technology and Standards: Seoul, Korea, 2014.

15. ISO. Fire-Resistance Tests-Elements of Building Construction-Part 1: General Requirements; ISO 834-1; International Organization for Standardization: Geneva, Switzerland, 1999.

16. ISO. Fire-Resistance Tests-Elements of Building Construction-Part 5: Specific Requirements for Loadbearing Horizontal Separating Elements; ISO 834-5; International Organization for Standardization: Geneva, Switzerland, 2000.

17. Buchanan, A.H.; Abu, A.K. Structural Design for Fire Safety, 2nd ed.; WILEY: Hoboken, NJ, USA, 2017.

18. Purkiss, J.A.; Li, L.Y. Fire Safety Engineering Design of Structures, 3rd ed.; CRC Press: Boca Raton, FL, USA, 2017.

19. Madhusudana, C.V. Thermal Contact Conductance, 2nd ed.; Springer: Berlin, Germany, 2014.

20. Ghojel, J. Application of Inverse Analysis to Thermal Contact Resistance between Very Rough Nonconforming Surfaces; Taylor \& Francis: Oxford, UK, 2002; Volume 10.

21. Ghojel, J. Experimental and analytical technique for estimating interface thermal conductance in composite structural elements under simulated fire conditions. Exp. Therm. Fluid Sci. 2004, 28, 347-354. [CrossRef]

22. Ding, J.; Wang, Y. Realistic modelling of thermal and structural behaviour of unprotected concrete filled tubular columns in fire. J. Constr. Steel. Res. 2008, 64, 1086-1102. [CrossRef]

23. Ding, J.; Wang, Y.C. Temperatures in unprotected joints between steel beams and concrete-filled tubular columns in fire. Fire Saf. J. 2009, 44, 16-32. [CrossRef]

24. Lu, H.; Zhao, X.L.; Han, L.H. Fire behaviour of high strength self-consolidating concrete filled steel tubular stub columns. J. Constr. Steel. Res. 2009, 65, 1995-2010. [CrossRef]

25. Espinos, A.; Romero, M.L.; Hospitaler, A. Advanced model for predicting the fire response of concrete filled tubular columns. J. Constr. Steel. Res. 2010, 66, 1030-1046. [CrossRef]

26. Tao, Z.; Ghannam, M. Heat transfer in concrete-filled carbon and stainless steel tubes exposed to fire. Fire Saf. J. 2013, 61, 1-11. [CrossRef]

27. Fuller, J.J.; Marotta, E. Thermal contact conductance of metal/polymer joints: An analytical and experimental investigation. J. Thermophys. Heat Transf. 2001, 15, 228-238. [CrossRef]

28. Bahrami, M.; Yovanovich, M.; Marotta, E. Modeling of thermal joint resistance of polymer-metal rough interfaces. In Proceedings of the 2004 ASME International Mechanical Engineering Congress, Anaheim, CA, USA, 13-19 November 2004.

29. Gibbins, J. Thermal Contact Resistance of Polymer Interfaces. Master's Thesis, University of Waterloo, Waterloo, ON, Canada, 2006.

30. Smith, A.L.; Hicks, S.J.; Devine, P.J. Design of Floors for Vibration: A New Approach; Steel Construction Institute: Berkshire, UK, 2007.

31. Murray, T.M.; Allen, D.; Ungar, E.E.; Davis, D.B. Vibrations of Steel-Framed Structural Systems Due to Human Activity, 2nd ed.; American Institute of Steel Construction: Chicago, IL, USA, 2016.

32. CEN. Eurocode 5: Design of Timber Structures-Part 1-2: General-Structural Fire Design, European Committee for Standardization; CEN: Brussels, Belgium, 2004.

33. NZS. Timber Structures Standard; NZS 3603:1903; Standards New Zealand: Wellington, New Zealand, 1993.

34. AWC. 2018 National Design Specification for Wood Construction; American Wood Council: Leesburg, VA, USA, 2017.

35. AWC. Calculating the Fire Resistance of Exposed Wood Members; American Wood Council: Leesburg, VA, USA, 2015.

36. Anjang, A.; Chevali, V.; Lattimer, B.; Case, S.; Feih, S.; Mouritz, A. Post-fire mechanical properties of sandwich composite structures. Compos. Struct. 2015, 132, 1019-1028. [CrossRef]

37. Wan, C.-Y.; Zha, X.-X.; Dassekpo, J.-B.M. Analysis of axially loaded concrete filled circular hollow double steel tubular columns exposed to fire. Fire Saf. J. 2017, 88, 1-12. [CrossRef]

38. Tan, Q.H.; Han, L.H.; Yu, H.X. Fire performance of concrete filled steel tubular (CFST) column to RC beam joints. Fire Saf. J. 2012, 51, 68-84. [CrossRef]

39. Hurley, M.J. The cone calorimeter. In SFPE Handbook of Fire Protection Engineering, 5th ed.; Springer: Berlin, Germany, 2016; Volume 1. 
40. Babrauskas, V. Development of the cone calorimeter-A bench-scale heat release rate apparatus based on oxygen consumption. Fire Mater. 1984, 8, 81-95. [CrossRef]

41. Zhang, Y.; Wang, Y.; Bailey, C.; Taylor, A. Global modelling of fire protection performance of intumescent coating under different cone calorimeter heating conditions. Fire Saf. J. 2012, 50, 51-62. [CrossRef]

42. Bartholmai, M.; Schriever, R.; Schartel, B. Influence of external heat flux and coating thickness on the thermal insulation properties of two different intumescent coatings using cone calorimeter and numerical analysis. Fire Mater. 2003, 27, 151-162. [CrossRef]

43. Yuen, R.; Yeoh, G.; de Vahl Davis, G.; Leonardi, E. Modelling the pyrolysis of wet wood-II. Three-dimensional cone calorimeter simulation. Int. J. Heat Mass Transf. 2007, 50, 4387-4399. [CrossRef]

44. Kuang-Chung, T.; Drysdale, D. Using cone calorimeter data for the prediction of fire hazard. Fire Saf. J. 2002, 37, 697-706. [CrossRef]

45. ASTM. Standard Test Method for Heat and Visible Smoke Release Rates for Materials and Products Using an Oxygen Consumption Calorimeter; ASTM E1354; American Society for Testing and Material: West Conshohocken, PA, USA, 1990.

46. ISO. Fire Tests, Reaction to Fire, Rate of Heat Release from Building Products; ISO. 5660; International Organization for Standardization: Geneva, Switzeland, 1993.

47. BS. Eurocode 3: Design of Steel Structures-Part 1-2: General Rules-Structural Fire Design; BS EN 1993-1-2:2005; British Standard: London, UK, 2005.

48. ASTM. Standard Test Method for Thermal Diffusivity by the Flash Method; ASTM E1461; American Society for Testing and Material: West Conshohocken, PA, USA, 2013.

49. Montgomery, R. Viscosity and thermal conductivity of air and diffusivity of water vapor in air. J. Meteorol. 1947, 4, 193-196. [CrossRef]

50. Fishenden, M.W.; Saunders, O.A. An Introduction to Heat Transfer; Clarendon Press: Oxford, UK, 1950.

51. Gilchrist, J.D. Furnaces; Pergamon press: Oxford, UK, 1963.

52. Thor, J. Strålningspåverkan På Oisolerade Eller Undertaksisolerade Stålkonstruktioner Vid Brand; Lund Institute of Technology: Lund, Sweden, 1972.

53. Pettersson, O.; Magnusson, S.E.; Thor, J. Fire Engineering Design of Steel Structures; Lund Institute of Technology: Lund, Sweden, 1976.

54. Croft, D.R.; Lilley, D.G. Heat Transfer Calculations Using Finite Difference Equations; Elsevier: Amsterdam, The Netherlands, 1977.

55. Wainman, D.; Kirby, B. Compendium of UK Standard Fire Test Data: Unprotected Structural Steel; British Steel Technical Swinden Laboratories: South Yorkshire, UK, 1989.

56. Both, C.; Twilt, L. TNO Building and Construction Research; Report No. BI-89-208; Netherlands Organization for Applied Scientific Research: South Holland, The Netherlands, 1990.

57. Huang, Z.; Platten, A.; Roberts, J. Non-linear finite element model to predict temperature histories within reinforced concrete in fires. Build. Environ. 1996, 31, 109-118. [CrossRef]

58. Kay, T.; Kirby, B.; Preston, R. Calculation of the heating rate of an unprotected steel member in a standard fire resistance test. Fire Saf. J. 1996, 26, 327-350. [CrossRef]

59. Ding, J.; Li, G.Q.; Sakumoto, Y. Parametric studies on fire resistance of fire-resistant steel members. J. Constr. Steel. Res. 2004, 60, 1007-1027. [CrossRef]

60. Franssen, J.M. SAFIR: A thermal/structural program for modeling structures under fire. Eng. J.-Am. Inst. Steel Constr. 2005, 42, 143-158.

61. Bratina, S.; Čas, B.; Saje, M.; Planinc, I. Numerical modelling of behaviour of reinforced concrete columns in fire and comparison with Eurocode 2. Int. J. Solids Struct. 2005, 42, 5715-5733. [CrossRef]

62. Gardner, L.; Ng, K. Temperature development in structural stainless steel sections exposed to fire. Fire Saf. J. 2006, 41, 185-203. [CrossRef]

63. Kodur, V.; Dwaikat, M. Effect of high temperature creep on the fire response of restrained steel beams. Mater. Struct. 2010, 43, 1327-1341. [CrossRef]

64. Dwaikat, M.; Kodur, V. A simplified approach for predicting temperature profile in steel members with locally damaged fire protection. Fire Technol. 2012, 48, 493-512. [CrossRef]

65. Lu, H.; Zhao, X.L.; Han, L.H. FE modelling and fire resistance design of concrete filled double skin tubular columns. J. Constr. Steel. Res. 2011, 67, 1733-1748. [CrossRef] 
66. Sadiq, H.; Wong, M.; Tashan, J.; Al-Mahaidi, R.; Zhao, X.L. Determination of steel emissivity for the temperature prediction of structural steel members in fire. J. Mater. Civ. Eng. 2012, 25, 167-173. [CrossRef]

67. Wang, Y.; Dong, Y.L.; Zhou, G.C. Nonlinear numerical modeling of two-way reinforced concrete slabs subjected to fire. Comput. Struct. 2013, 119, 23-36. [CrossRef]

68. Wang, Y.; Yuan, G.; Huang, Z.; Lyu, J.; Li, Q.; Long, B. Modelling of reinforced concrete slabs in fire. Fire Saf. J. 2018, 100, 171-185. [CrossRef]

69. Agwu Nnanna, A.G.; Haji-Sheikh, A. Sensivity coefficients for experimental estimation of interstitial properties during phase change in porous media. Inverse Probl. Sci. Eng. 2005, 13, 595-616. [CrossRef]

(C) 2020 by the authors. Licensee MDPI, Basel, Switzerland. This article is an open access article distributed under the terms and conditions of the Creative Commons Attribution (CC BY) license (http://creativecommons.org/licenses/by/4.0/). 